\title{
Assessment of Dairy Cattle Management in Gurage Zone, Southern Nation Nationalities and Peoples Region, Ethiopia
}

\author{
Tesfaye Feyisa Aduna ${ }^{1 *}$, Wondossen Ayalew ${ }^{1}$ \\ ${ }^{1}$ Department of Animal Production and Technology, Wolkite University, Ethiopia
}

*Corresponding Author: Tesfaye Feyisa Aduna, Department of Animal Production and Technology, Wolkite University, Ethiopia

\begin{abstract}
Management practices such as feeding, watering, housing and health management of dairy cattle were studied in Gurage Zone, Southern Nation Nationalities and peoples Regional State. In all studied areas, crop residues, natural grazing and hay were the three top livestock feed resources. Despite this, households make insignificant quantity of concentrate and face critical feed shortage during the dry season. Critical shortage of water was also noted during the dry season, particularly in Wolkite town. Shortage of animal feeds, land and water scarcity were the major constraints for dairy development in the study area. Supplementary feed and letting the animals to graze were the major utilization practices of feed resource. Three types of diseases namely FMD, Diarrhea and Anthrax were identified as the major health problem of cattle. Rapid urbanization coupled with increase in human population, standard way of life of the urban dwellers and conducive climate of the area can be considered as an opportunity for the development of dairy in the area. Therefore, market opportunity and linkages are the major issues for smallholder dairy development in addition to provision of the required services and resources, provision of credit, extension and training. However, there is a need for intervention to develop infrastructure, enhance input supply system, and undertake capacity development and training to enhance the skills of farmers in dairy production and marketing. Attention should also be given to effective veterinary services, improved feed production and conservation systems, feeding strategies and systems.
\end{abstract}

Keywords: Gurage Zone, Dairy cattle, Management practices

\section{INTRODUCTION}

Currently, the population of livestock found in Ethiopia is estimated to be 53.4 million cattle, 25.5 million sheep, 22.78 million goats and 2.3 million camels (CSA 2011). Despite these huge numbers, the contribution of livestock was very low. The contribution of livestock to the total agricultural GDP and the national foreign currency is about $30 \%$ and 16\%, respectively (Institution of Biodiversity Conservation, 2004). With an average lactation length of 6 months and an average daily milk production of 1.54 litters per cow/day, the total milk produced during the year 2009 was recorded to be 4.06 billion litters (CSA, 2009), and the per capita milk consumption was only about $16 \mathrm{~kg} / \mathrm{year}$, which is much lower than African and world per capita averages of $27 \mathrm{~kg} /$ year and $100 \mathrm{~kg} /$ year, respectively (FAOSTAT, 2009).

Additionally, the annual rate of increase in milk yield (estimated to be $1.2 \%$ ) lags behind the increment in human population (estimated to be about 2.7\% per annum) (CSA, 2008) and this resulted in large supply-demand variance for fresh milk (MoARD, 2004). This is due to various factors among which inadequate feed resource both in quantity and quality, lack of appropriate feeding system, prevalent livestock health problems and lack of well-developed dairy health management systems are the major ones (Yoseph et al., 2003).

Reproductive performance is often a major determinant of biological and economic efficiency of milk production in tropics which in turn depend up on the above factors in addition to breed. Previous studies have shown crossbred animals to have better reproductive and productivity performances compared with indigenous stock (Alberro, 1983; Kiwuwa et al., 1983; Yoseph et.al., 2003). However, their relative advantage depends upon provision of adequate nutrition and better health management (Preston, 1989). Failure to attain sexual maturity at early age and prolonged age at first calving, 
increased number of services per conception, longer calving intervals and great loss of valuable productive animals are the major problems which were mainly related with husbandry/management practices.

Thus, appropriate reproductive and productive management methods are highly desired within the dairy production systems. These have to be designed by improving the aforementioned problems. To meet the ever-increasing demand for milk, milk products and thus contribute to economic growth, improvement of husbandry practices has been proposed as one of the options. However, in Guraghe zone, such work has not been conducted to take corrective measurement that increases the productivity and reproductive performance of dairy cows in the Zone. Therefore, this study was conducted to assess the major husbandry practices of dairy cattle in Guraghe zone.

\section{Materials ANd Methods}

\subsection{Description of the Study Area}

The study was conducted in Gurage Zone, which is located $155 \mathrm{~km}$ from the capital city (Addis Ababa). The Zone is located between $7.8^{0}-8.5^{\circ}$ North latitude and $37.5^{\circ} \mathrm{C}-38.7^{0}$ East longitude of the equator. The zone comprises altitudes ranging from 1,001 to 3,500 meters above sea level (m.a.s.l). Mean annual temperature of the zone ranges from 13 to $30^{\circ} \mathrm{c}$ and mean annual rain fall ranges from 600 to $1600 \mathrm{~mm}$. The land utilization data of the region indicated that about 298,369 ha were cultivated land, 67,678ha were covered by forest, bushes and shrub, 70,249.31ha were considered as grazing land, and 14,234 ha of land were covered by others (GZADD, 2011).

\subsection{Sampling Technique and Sample Size Determination}

Both systematic and random sampling methods were used. For this purpose, the zone was divided into three using agro- ecological zones as criteria, as it is generally believed; the farming systems, mode of life and many more characteristics vary across altitude zones (Holecheck et al., 2005). Thus, three districts (Enmore from low land, Mareko from mid land and Geta from high land), and Wolkite town were selected purposively. Wolkite town was taken by considering that, the management system of dairy production in the town might be different from rural areas. Then from each agro-ecology, two kebeles were selected by using simple random sampling method with a total of eight kebeles. Lastly, 45 households were selected from each selected district randomly making a total of 180 households.

\subsection{Methods of Data Collection}

The data were collected from both primary and secondary sources. The primary data was collected through pretested semi-structure questionnaires and field observations. The core points of questionnaires were feed resource and feeding system, water resource and watering system, housing system, and cattle health care. While the secondary data were obtained from the zone and woreda agricultural offices, Journal articles and books.

\subsection{Data Analysis}

The collected data was analyzed by SPPS version 20 software (SPSS, 2015). Then the data was summarized by using simple descriptive statistics such as mean and percentile.

\section{RESULTS AND DISCUSSIONS}

\subsection{Household Characteristics}

Among the investigated households, $81.1 \%$ were male-headed, while the remaining (18.9\%) respondents were female-headed households (Table 1). The overall mean age of respondents was about of 42.1 years (Table 1). This indicates that family members in the productive age group were higher than that of the non-productive age groups (dependents). The mean age of Geta districts was significantly higher $(\mathrm{P}<0.5)$ than other study areas. The overall educational status of the households indicated that majority $(57.2 \%)$ of them were illiterate followed by read and write (23.3\%), primary school (13.3\%), secondary school $(3.9 \%)$ and above secondary school $(2.2 \%)$. The low level of educational status in the study area may exert adverse impact on technology transfer and hamper the productivity of the interventions being made in the district. The average family size of households in the study area was almost similar with the overall mean family size of $5.86 \pm(0.13)$ person per family. 
Assessment of Dairy Cattle Management in Gurage Zone, Southern Nation Nationalities and Peoples Region, Ethiopia

The mean family size obtained in the study district was higher than the national average (5.2) as reported by CACC (2002).

Table1. House hold sex, age and relative frequency with different educational background in study districts

\begin{tabular}{|c|c|c|c|c|c|c|c|c|c|c|}
\hline \multirow[t]{2}{*}{ Variables } & \multicolumn{2}{|c|}{ Enemor } & \multicolumn{2}{|l|}{ Geta } & \multicolumn{2}{|c|}{ Mareko } & \multicolumn{2}{|c|}{ Wolkite } & \multicolumn{2}{|c|}{ Overall } \\
\hline & $\mathrm{HHC}$ & $\%$ & HHC & $\%$ & $\mathrm{HHC}$ & $\%$ & $\mathrm{HHC}$ & $\%$ & \begin{tabular}{l|l}
$\mathrm{HHC}$ &
\end{tabular} & $\%$ \\
\hline HH head sex & $\mathrm{N}=45$ & & $\mathrm{~N}=45$ & & $\mathrm{~N}=45$ & & $\mathrm{~N}=45$ & & 180 & \\
\hline $\begin{array}{l}\text { Male } \\
\text { headed }\end{array}$ & 37 & 82.2 & 41 & 91.1 & 34 & 75.6 & 39 & 86.7 & 146 & 81.1 \\
\hline $\begin{array}{l}\text { Female } \\
\text { headed }\end{array}$ & 8 & 17.7 & 4 & 8.9 & 11 & 24.4 & 6 & 13.3 & 34 & 18.9 \\
\hline $\begin{array}{l}\text { Mean age } \\
(\mathrm{SE})\end{array}$ & $38.5(1.34)^{\mathrm{a}}$ & & $47.2(1.42)^{b}$ & & $40.5(1.72)^{\mathrm{a}}$ & & $42.4(1.07)^{\mathrm{a}}$ & & 42.1(0.74) & \\
\hline $\begin{array}{l}\text { Educational } \\
\text { background }\end{array}$ & $\mathrm{N}=45$ & & $\mathrm{~N}=45$ & & $\mathrm{~N}=45$ & & $\mathrm{~N}=45$ & & $\mathrm{~N}=180$ & \\
\hline Illiterate & 29 & 64.4 & 34 & 68.9 & 22 & 48.9 & 18 & 40 & 103 & 57.2 \\
\hline $\begin{array}{l}\text { Read and } \\
\text { write }\end{array}$ & 8 & 13.3 & 7 & 15.6 & 14 & 31.1 & 13 & 51.1 & 42 & 23.3 \\
\hline $\begin{array}{l}\text { Primary } \\
\text { school }\end{array}$ & 5 & 11.1 & 3 & 6.7 & 7 & 15.6 & 9 & 20 & 24 & 13.3 \\
\hline $\begin{array}{l}\text { Secondary } \\
\text { school }\end{array}$ & 2 & 4.4 & 1 & 2.2 & 0 & 0 & 4 & 8.9 & 7 & 3.9 \\
\hline $\begin{array}{c}\text { Above } \\
\text { seco. School }\end{array}$ & 1 & 2.2 & 0 & 0 & 2 & 4.4 & 1 & 2.2 & 4 & 2.2 \\
\hline Family size & & & & & & & & & & \\
\hline Male & $2.73 \pm 0.15$ & & $3.45 \pm 0.20$ & & $2.80 \pm 0.17$ & & $2.51 \pm 0.15$ & & $2.88 \pm 0.09$ & \\
\hline Female & $2.98 \pm 0.20$ & & $3.36 \pm 0.15$ & & $2.44 \pm 0.18$ & & $3.34 \pm 0.22$ & & $3.03 \pm 0.10$ & \\
\hline Total & $5.59 \pm 0.32$ & & $6.85 \pm 0.21$ & & $5.27 \pm 0.21$ & & $5.78 \pm 0.28$ & & $5.86 \pm 0.13$ & \\
\hline
\end{tabular}

$N=$ number of interviewed, $H H C=$ household characteristics

\subsection{Land Holding}

Mean value of sample farms land holding and cropping patterns of selected districts of Gurage Zone are depicted on Table 2. The mean land holding of study area was $2.12 \mathrm{ha}$. The mean of farm size allocation to own farm land for food crop, own area under forage/pasture, area under fallow land, grazing land, perennial crop, rented land for food crop, rented land for pasture/forage and rented land for grazing were $1.1,0.29,0.23,0.35,0.2,0.28,0.25$ and 0.33 ha, respectively. This implies that a large proportion of farm size was allocated to crop production. Only 0.35 and 0.29 hectares were used for grazing and forage development, respectively which have an influence on dairy cattle production. The function of dairy cattle production depends up on the availability of feed resources in quantity and quality which in turn depend up on the availability of land for forage developments. This is due to growing of on farm forage mainly legume species improve the production and reproduction of animals by reducing the cost of production. But, with the rapid increase of human population and increasing demand for food, grazing lands are steadily shrinking by being converted to arable lands, and are restricted to areas that have little value or farming potential such as hilltops, swampy areas, roadsides and other marginal land.

Table2. Mean of Land Holding in the Study Districts

\begin{tabular}{|c|c|c|c|c|c|c|c|c|c|c|c|c|}
\hline $\begin{array}{c}\text { Owner ship } \\
\text { (ha) }\end{array}$ & \multicolumn{3}{|c|}{ Enemor } & \multicolumn{3}{c|}{ Geta } & \multicolumn{3}{c|}{ Mareko } & \multicolumn{3}{c|}{ Wolkite } \\
\cline { 2 - 13 } & Min & Max & $\begin{array}{c}\text { Mean } \\
\text { (ha) }\end{array}$ & Min & Max & $\begin{array}{c}\text { Mean } \\
\text { (ha) }\end{array}$ & Min & Max & $\begin{array}{c}\text { Mean } \\
\text { (ha) }\end{array}$ & Min & $\begin{array}{c}\text { Max } \\
\text { Mean } \\
\text { (ha) }\end{array}$ \\
\hline $\begin{array}{c}\text { Own crop } \\
\text { land }\end{array}$ & 0 & 3 & 0.96 & 0.5 & 3 & 1.67 & 0 & 1.5 & 0.75 & 0 & 0.5 & 0.25 \\
\hline $\begin{array}{c}\text { Rented crop } \\
\text { land }\end{array}$ & 0 & 0.75 & 0.41 & 0.25 & 1 & 0.57 & 0 & 1 & 0.14 & & 1.5 & 0.21 \\
\hline Own & 0 & 2 & 0.54 & 0 & 1.5 & 0.19 & 0 & 2 & 0.8 & 0 & 2 & 0.26 \\
\hline $\begin{array}{c}\text { Pasture land } \\
\text { Rented }\end{array}$ & 0.25 & 1 & 0.56 & 0 & 1 & 0.21 & 0 & 1 & 0.17 & 0 & 1 & 0.23 \\
\hline $\begin{array}{c}\text { Pasture land } \\
\text { Total }\end{array}$ & & 2.47 & & & 2.64 & & & 1.26 & & & 0.49 \\
\hline
\end{tabular}




\subsection{Herd Size and Species Composition}

Cattle, horse, donkeys and chickens were reared by the local community of all study areas (Table 3). There was variation in size of herd per house hold from one woreda to another woreda. Goat and sheep were found in some woredas as it was reported by respondents. This might be due to the unsuitability of agro-ecology as it was known that goat prefers lowlands due to their browsing habit and sheep needs midlands and highlands than lowlands.

Table3. Overall composition of livestock (head/HH) in the study areas

\begin{tabular}{|c|c|c|c|c|c|}
\hline & Enemor & Geta & Mareko & Wolkite & Overall \\
\hline & Mean \pm SE & Mean \pm SE & Mean \pm SE & Mean \pm SE & Mean \pm SE \\
\hline Herd type & $\mathrm{N}=45$ & $\mathrm{~N}=45$ & $\mathrm{~N}=45$ & $\mathrm{~N}=45$ & $\mathrm{~N}=45$ \\
\hline Cattle & & & & & \\
\hline Cow & $2.62 \pm 0.17$ & $1.05 \pm 0.03$ & $2.40 \pm 0.18$ & $1.00 \pm 0.00$ & $1.94 \pm 0.10$ \\
\hline Calf & $1.32 \pm 0.10$ & - & $1.5 \pm 0.09$ & - & $1.46 \pm 0.07$ \\
\hline Heifers & $1.68 \pm 0.09$ & $3.07 \pm 0.15$ & $1.32 \pm 0.09$ & $1.84 \pm 0.11$ & $2.02 \pm 0.08$ \\
\hline Oxen & $1.50 \pm 0.16$ & $2.20 \pm 0.29$ & $1.42 \pm 0.16$ & $1.25 \pm 0.14$ & $1.49 \pm 0.08$ \\
\hline Sheep & $1.18 \pm 0.08$ & $3.00 \pm 0.44$ & $5.25 \pm 0.64$ & - & $2.77 \pm 0.30$ \\
\hline Goat & $5.75 \pm 0.99$ & - & $4.00 \pm 0.00$ & - & $5.50 \pm 0.86$ \\
\hline Donkey & $1.43 \pm 0.12$ & $1.25 \pm 0,13$ & $1.60 \pm 0.13$ & $1.00 \pm 0.0$ & $1.14 \pm 0.07$ \\
\hline Horse & $2 . .50 \pm 0.22$ & $1.22 \pm 0.15$ & $1.22 \pm 0.15$ & $1.25 \pm 0.25$ & $1.76 \pm 0.15$ \\
\hline Mule & $1.00 \pm 0.0$ & $1.18 \pm 0.08$ & - & - & $1.00 \pm 00$ \\
\hline Chicken & $4.83 \pm 0.56$ & $3.63 \pm 0.100$ & $7.71 \pm 0.77$ & $4.83 \pm 0.56$ & $4.85 \pm 0.33$ \\
\hline
\end{tabular}

$N=$ number of interviewed households, $S E=$ standard error

\subsection{Sources of Income in the Study Districts}

Major sources of income used as a source of cash in the study district were presented in table 4 . Live animals and crop sale were the major source of cash income for all study districts. Majority $(66.67 \%)$ of respondents used both crop and livestock income sources indicating that both of them contribute valuable commodities for the livelihood of farmers. This is important for both home consumption and for other cash need in case of difficulty. But, selling of any crop/livestock for the sources of cash in the household was dependent on the amount of money needed to cover their expense. Cattle were sold to cover large expenses and crop was sold for relatively smaller expenditures. However, crop was used as a source of cash when there is a surplus from household consumption.

Table4. Sources of income in the study districts

\begin{tabular}{|c|c|c|c|c|c|c|c|}
\hline \multirow{3}{*}{ № } & \multirow{3}{*}{ Districts } & \multicolumn{6}{|c|}{ Income Sources of the Respondents } \\
\hline & & \multicolumn{2}{|c|}{ Crop production } & \multicolumn{2}{|c|}{ Livestock production } & \multicolumn{2}{|c|}{ Both crop and livestock } \\
\hline & & No & $\%$ & No & $\%$ & No & $\%$ \\
\hline 1 & Wolkite & 11 & 24.44 & $1 \overline{7}$ & 37.78 & $1 \overline{7}$ & 37.78 \\
\hline 2 & Enmore & 3 & 6.67 & 14 & 31.11 & 28 & 62.22 \\
\hline 3 & Geta & 0 & 0 & 0 & 0 & 45 & 100 \\
\hline 4 & Mareko & 7 & 15.56 & 8 & 17.78 & 30 & 66.67 \\
\hline & Total & 21 & 11.66 & 39 & 21.67 & 120 & 66.67 \\
\hline
\end{tabular}

\subsection{Dairy Cattle Feed Resources}

The ranking in availability of feed resources and preference of farmers to the feed resources in all study areas were shown in table 5. The main feed resources to dairy cattle in the study area were natural pasture, crop residues, crop after math grazing, concentrate, Atela and hay, which agrees with earlier reports (Alemayehu, 2004; Bayane et al., 2011). Crop residues were ranked as the primary source of feed to dairy animals in Geta woreda and Marako woreda (Table 5). Natural grazing was ranked $2^{\text {nd }}$ followed by hay in Geta and Marako woreda. In wolkite town, hay ranked $2^{\text {nd }}$ next to crop residues followed by natural grazing. However, in Enamor woreda using of hay as a feed resources was ranked first followed by crop residues and natural grazing, respectively. The least in the order of importance as feed resource in the study area was crop after math. This might be due to unavailability of after math grazing in wet season. 
Assessment of Dairy Cattle Management in Gurage Zone, Southern Nation Nationalities and Peoples Region, Ethiopia

Hay was an important feed resource which is conserved to feed animals during dry season even if the majority (79.44\%) of respondents in the study area were not participated on the development of forage production (table 7). The major reason why the peoples in the study area were not participated on forage development might be due to insufficient land (81.12\%) and insufficient input (18.88\%) (Table 7) indicating availability of land was a corner stone for the development of forage.

Generally, in all study areas; crop residues, natural pasture and hay were the top three livestock feed resources. With the rapid increase of human population and expansion of crop land, the use of crop residues is increasing which agrees with earlier report (Alemayehu, 2006).

Table5. Feed resources for dairy cattle in study districts

\begin{tabular}{|c|c|c|c|c|c|c|}
\hline \multirow{2}{*}{$\begin{array}{c}\text { Study } \\
\text { Districts }\end{array}$} & \multirow[b]{2}{*}{ Feed resource } & \multicolumn{5}{|c|}{ Rank (No HHs) } \\
\hline & & 1 & 2 & 3 & 4 & Index $*$ \\
\hline \multirow[t]{6}{*}{ Enemor } & Natural grazing & 15 & 7 & 4 & 0 & 0.052 \\
\hline & Crop residue & 18 & 13 & 8 & 2 & 0.076 \\
\hline & Crop after math & 0 & 0 & 4 & 2 & 0.006 \\
\hline & Concentrate & 0 & 0 & 21 & 24 & 0.039 \\
\hline & Atela & 0 & 6 & 14 & 15 & 0.036 \\
\hline & Hay & 19 & 13 & 5 & 6 & 0.077 \\
\hline \multirow[t]{6}{*}{ Geta } & Natural grazing & 19 & 5 & 3 & 12 & 0.064 \\
\hline & Crop residue & 26 & 10 & 4 & 0 & 0.084 \\
\hline & Crop after math & 0 & 0 & 1 & 0 & 0.001 \\
\hline & Concentrate & 0 & 0 & 3 & 8 & 0.008 \\
\hline & Atela & 0 & 0 & 1 & 2 & 0.002 \\
\hline & Hay & 15 & 21 & 6 & 1 & 0.08 \\
\hline \multirow[t]{6}{*}{ Mareko } & Natural grazing & 18 & 13 & 15 & 9 & 0.088 \\
\hline & Crop residue & 26 & 11 & 7 & 1 & 0.089 \\
\hline & Crop after math & 0 & 0 & 2 & 5 & 0.005 \\
\hline & Concentrate & 0 & 0 & 2 & 8 & 0.007 \\
\hline & Atela & 0 & 0 & 6 & 3 & 0.009 \\
\hline & Hay & 22 & 17 & & 0 & 0.082 \\
\hline \multirow[t]{6}{*}{ Wolkite } & Natural grazing & 2 & 11 & 5 & 4 & 0.032 \\
\hline & Crop residue & 12 & 9 & 14 & 11 & 0.067 \\
\hline & Crop after math & 0 & 0 & 0 & 2 & 0.001 \\
\hline & Concentrate & 0 & 4 & 2 & 13 & 0.017 \\
\hline & Atela & 1 & 0 & 7 & 0 & 0.011 \\
\hline & Hay & 21 & 6 & 5 & 0 & 0.066 \\
\hline
\end{tabular}

$*$ Index $=$ sum of single livestock species sale ranks [ 4 for rank 1$)+(3$ for rank 2$)+(2$ for rank 3$)+(1$ for rank 4)] divided by sum of all weighed livestock sales mentioned by the respondents in each production system

\subsection{Dairy Cattle Feeding Systems}

The utilization practices of dairy animals were different from one agro-ecology to another which was mainly depend up on the availability of feed resource and the purpose of keeping dairy animals. More than $67 \%$ of respondents in all study areas mentioned as the utilization practices of the feed in the study area were semi grazing (Table 6). This might be due to the land is not sufficient enough for the growth of forage which was thoroughly used for grazing. Only $1 \%$ of them were used full grazing indicating the scarcity of land for entire grazing might be due to the large proportion of farm size was allocated to crop production (Table 2).

Table6. Dairy cattle feeding systems

\begin{tabular}{|c|c|c|c|c|c|c|c|c|c|c|c|}
\hline \multirow[t]{3}{*}{ No } & \multirow[t]{3}{*}{ Grazing system } & \multicolumn{8}{|c|}{ Study areas } & \multirow{2}{*}{\multicolumn{2}{|c|}{ Total }} \\
\hline & & \multicolumn{2}{|c|}{ Wolkite town } & \multicolumn{2}{|c|}{ Enamore } & \multicolumn{2}{|c|}{ Geta } & \multicolumn{2}{|c|}{ Marako } & & \\
\hline & & No & $\%$ & No & $\%$ & No & $\%$ & No & $\%$ & No & $\%$ \\
\hline 1 & Zero grazing & 15 & 33.33 & 25 & 55.56 & 12 & 26.67 & 5 & 11.11 & 57 & 31.67 \\
\hline 2 & Semi grazing & 30 & 66.67 & 20 & 44.44 & 33 & 73.33 & 38 & 84.44 & 121 & 67.22 \\
\hline 3 & Full grazing & 0 & 0 & 0 & 0 & 0 & 0 & 2 & 4.44 & 2 & 1.11 \\
\hline & Total & 45 & 100 & 45 & 100 & 45 & 100 & 45 & 100 & 180 & 100 \\
\hline
\end{tabular}

No= number of interviewed households 
Assessment of Dairy Cattle Management in Gurage Zone, Southern Nation Nationalities and Peoples Region, Ethiopia

\section{SOURCES OF FEed IN THE STUdy AREAS}

There were three sources of feeds in the study area; producing on their own land $(11.67 \%)$, purchasing from somewhere $(65.55 \%)$ and combination of them $(22.78 \%)$. This indicated that, the majority of respondents $(65.55 \%)$ in the study area bought supplementary feeds, and the major supplementary feeds they used were oilseed cakes $(56.63 \%)$, flour milling by product $(37.35 \%)$ and brewery spent grains $(6.02 \%)$ (Table7).

Table7. Sources of feed in the study areas

\begin{tabular}{|c|c|c|c|c|c|c|c|c|c|c|}
\hline \multirow[t]{3}{*}{ Variables } & \multicolumn{8}{|c|}{ Study Districts } & \multirow{2}{*}{\multicolumn{2}{|c|}{ Total }} \\
\hline & \multicolumn{2}{|c|}{ Wolkite town } & \multicolumn{2}{|c|}{ Enamor } & \multicolumn{2}{|c|}{ Geta } & \multicolumn{2}{|c|}{ Mareko } & & \\
\hline & $\mathrm{N}$ & $\%$ & $\mathrm{~N}$ & $\%$ & $\mathrm{~N}$ & $\%$ & $\mathrm{~N}$ & $\%$ & $\mathrm{~N}$ & $\%$ \\
\hline $\mathrm{P}$ Sources of feed & & & & & & & & & & \\
\hline Own production & 0 & 0 & 0 & 0 & 0 & 0 & 21 & 46.67 & 21 & 11.67 \\
\hline Purchased & 23 & 51.11 & 45 & 100 & 45 & 100 & 5 & 11.11 & 118 & 65.55 \\
\hline Both & 22 & 48.89 & 0 & 0 & 0 & 0 & 19 & 42.22 & 41 & 22.78 \\
\hline $\begin{array}{l}\text { Purchased feed } \\
\text { supplement? }\end{array}$ & & & & & & & & & & \\
\hline Yes & 44 & 97.78 & 45 & 100 & 44 & 97.78 & 33 & 73.33 & 166 & 92.22 \\
\hline No & 1 & 2.22 & 0 & 0 & 1 & 2.22 & 12 & 26.67 & 14 & 7.78 \\
\hline $\begin{array}{l}\text { Types of feed } \\
\text { supplement } \\
\text { purchased }\end{array}$ & & & & & & & & & & \\
\hline Oilseed cake & 3 & 6.82 & 21 & 46.67 & 42 & 95.45 & 28 & 84.85 & 94 & 56.63 \\
\hline $\begin{array}{l}\text { Flour milling by } \\
\text { product (frushika) }\end{array}$ & 31 & 70.45 & 24 & 53.33 & 2 & 4.55 & 5 & 15.15 & 62 & 37.35 \\
\hline $\begin{array}{l}\text { Brewery spent } \\
\text { grains }\end{array}$ & 10 & 22.73 & 0 & 0 & 0 & 0 & 0 & 0 & 10 & 6.02 \\
\hline $\begin{array}{l}\text { Organizations/place } \\
\text { from w/c they } \\
\text { purchase }\end{array}$ & & & & & & & & & & \\
\hline Farmer association & 12 & 27.27 & 44 & 97.78 & 32 & 72.73 & 13 & 39.39 & 101 & 60.84 \\
\hline From industries & 0 & & 0 & 0 & 2 & 4.55 & 0 & 0 & 2 & 1.20 \\
\hline $\begin{array}{l}\text { From privates } \\
\text { retailers }\end{array}$ & 32 & 72.73 & 1 & 2.22 & 10 & 22.73 & 20 & 60.61 & 63 & 37.95 \\
\hline
\end{tabular}

\subsection{Seasons and Consequences of Feed Shortage, and Mechanisms Used to Reduce it}

Feed is one of the major factors that affect the productivity and reproductive of dairy cattle. In the study area, more than $88 \%$ of household respond as there were problems of feed shortage. Seasons of feed shortage in the study area were during wet season (39.42\%), dry season (32.12\%) and short rainy seasons $(28.47 \%)$ (Table 8). The mechanisms used to reduce feed shortage in the study area were; conserving feeds $(16.06 \%)$, purchasing crop residues and hay $(46.72 \%)$, purchasing concentrates (5.84) and selling animals (31.39\%). The consequence of feed shortage in the study area as ranked by respondents were: reduction in milk yield $(71.53 \%)$ and ranked $1^{\text {st }}$, weight loss $(21.90) 2^{\text {nd }}$, reduced fertility $(5.11 \%) 3^{\text {rd }}$ and increased mortality $(1.46 \%) 4^{\text {th }}$. This indicates that, feed shortage results in reduction of day milk yield so as the lactation milk yield of the animals also decreased. This is due to milk is the conversion of feed.

Table8. Seasons and consequences of feed shortage, and mechanisms used to reduce feed shortage

\begin{tabular}{|c|c|c|c|c|c|c|c|c|c|c|}
\hline \multirow[t]{3}{*}{ Variables } & \multicolumn{8}{|c|}{ Study Districts } & \multirow{2}{*}{\multicolumn{2}{|c|}{ Total }} \\
\hline & \multicolumn{2}{|c|}{$\begin{array}{c}\text { Wolkite } \\
\text { town }\end{array}$} & \multicolumn{2}{|c|}{ Enamore woreda } & \multicolumn{2}{|c|}{ Getta woreda } & \multicolumn{2}{|c|}{$\begin{array}{l}\text { Marako } \\
\text { Woreda }\end{array}$} & & \\
\hline & $\mathrm{N}$ & $\%$ & $\mathrm{~N}$ & $\%$ & $\mathrm{~N}$ & $\%$ & $\mathrm{~N}$ & $\%$ & $\mathrm{~N}$ & $\%$ \\
\hline $\begin{array}{c}\text { P Shortage of } \\
\text { feeds? }\end{array}$ & & & & & & & & & & \\
\hline$>$ Yes & & & & & & & & & & \\
\hline$>\mathrm{No}$ & 5 & 11.11 & 11 & 24.44 & 0 & 0 & 4 & 8.89 & 20 & 11.11 \\
\hline $\begin{array}{c}\text { Seasons of feed } \\
\text { shortage }\end{array}$ & & & & & & & & & & \\
\hline$>$ Dry season & 31 & 77.5 & 34 & 100 & 0 & 0 & 2 & 4.89 & 67 & 41.88 \\
\hline$>$ Wet season & 0 & 0 & 0 & 0 & 45 & 100 & 9 & 21.95 & 54 & 33.75 \\
\hline
\end{tabular}

International Journal of Research Studies in Agricultural Sciences (IJRSAS) 
Assessment of Dairy Cattle Management in Gurage Zone, Southern Nation Nationalities and Peoples Region, Ethiopia

\begin{tabular}{|c|c|c|c|c|c|c|c|c|c|c|}
\hline $\begin{array}{c}\text { Short rainy } \\
\text { season }\end{array}$ & 9 & 22.5 & 0 & 0 & 0 & 0 & 30 & 73.17 & 39 & 24.37 \\
\hline \multicolumn{11}{|l|}{$\begin{array}{l}\text { Mechanisms } \\
\text { used to reduce } \\
\text { feed shortage }\end{array}$} \\
\hline $\begin{array}{l}>\text { Feed } \\
\text { conservations }\end{array}$ & 10 & 25 & 0 & 0 & 0 & 0 & 12 & 29.27 & 22 & 13.75 \\
\hline $\begin{array}{c}\text { Purchasing } \\
\text { crop residues } \\
\text { and hay }\end{array}$ & 7 & 17.5 & 4 & 11.76 & 31 & 68.89 & 25 & 60.98 & 67 & 41.88 \\
\hline$>$ Sell animals & 17 & 42.5 & 30 & 88.24 & 14 & 31.11 & 2 & 4.88 & 63 & 39.37 \\
\hline $\begin{array}{l}\text { Purchase } \\
\text { concentrate }\end{array}$ & 6 & 15 & 0 & 0 & 0 & 0 & 2 & 4.88 & 8 & 5 \\
\hline \multicolumn{11}{|l|}{$\begin{array}{c}\text { Consequences of } \\
\text { feed shortage }\end{array}$} \\
\hline$>$ Weight loss & 1 & 2.5 & 4 & 11.76 & 11 & 24.44 & 16 & 39.02 & 32 & 20 \\
\hline $\begin{array}{c}\text { Reduction in } \\
\text { milk yield }\end{array}$ & 32 & 80 & 30 & 88.24 & 34 & 75.56 & 23 & 59.10 & 119 & 74.38 \\
\hline $\begin{array}{l}\text { Increased } \\
\text { mortality }\end{array}$ & 0 & 0 & 0 & 0 & 0 & 0 & 2 & 4.88 & 2 & 1.25 \\
\hline $\begin{array}{c}\text { Reduced } \\
\text { fertility }\end{array}$ & 7 & 17.5 & 0 & 0 & 0 & 0 & 0 & 0 & 7 & 4.37 \\
\hline
\end{tabular}

\subsection{Source, Distance and Frequency of Water for Dairy Cattle in the Study Areas}

The main sources of water observed in the present study area were rivers, pond and city pipe according to their importance. The majority $(52.22 \%)$ of the households in the rural areas obtain water from rivers even though its quality and availability were season dependent, while $33.89 \%$ from pond water and $13.89 \%$ from city pipe line (Table 9). As observed from the study, households that use river water for their animals do not treat it except in a few cases where households filter the water with the intention of preventing susceptibility to internal parasites.

Frequency of watering to dairy animals varies from one production system to another, which is affected by different factors, among which season, accessibility (getting easily), performance and/or breed of the animals (that describes the amount of water), and type of predominant feed (dry or wet) and feeding systems (indoor or outdoor where some water is available). In the wet season, the majority (70.6\%) of the respondents water their cattle once a day and minor (29.4\%) offer water twice a day (Table 9). During the dry season, $63.9 \%$ of the households provide water to their animals once a day except the household that live around or near watering points or rivers $(36.1 \%)$ which water their dairy animals twice. But, this condition was not persistent in the town since they use tape water; it is relatively freely available irrespective of season.

Table9. Source, distance and frequency of water for livestock

\begin{tabular}{|c|c|c|c|c|c|}
\hline \multirow[b]{2}{*}{ Variables } & \multicolumn{5}{|c|}{ Study Districts } \\
\hline & Enmor & Geta & Mareko & Wolkite & Over all \\
\hline & HHC (\%) & $\mathrm{HHC}(\%)$ & $\mathrm{HHC}(\%)$ & $\mathrm{HHC}(\%)$ & HHC (\%) \\
\hline Sources of water & $\mathrm{N}=45$ & $\mathrm{~N}=45$ & $\mathrm{~N}=45$ & $\mathrm{~N}=45$ & $\mathrm{~N}=180$ \\
\hline City pipe line & $1(2.22)$ & $0(0.00)$ & $10(22.22)$ & $14(31.11)$ & $25(13.89)$ \\
\hline Pond & $41(91.11)$ & $14(31.11)$ & $5(11.11)$ & $1(2.22)$ & $61(33.89)$ \\
\hline River & $3(6.67)$ & $31(68.89)$ & $30(66.67)$ & $30(66.67)$ & $94(52.22)$ \\
\hline Water distance & $\mathrm{N}=45$ & $\mathrm{~N}=45$ & $\mathrm{~N}=45$ & $\mathrm{~N}=45$ & $\mathrm{~N}=180$ \\
\hline$<1 \mathrm{~km}$ & $18(27.7)$ & $12(18.5)$ & $20(30.8)$ & $15(23.1)$ & $65(36)$ \\
\hline $2-5 \mathrm{~km}$ & $20(19.2)$ & $33(31.7)$ & $24(23.1)$ & $27(26.0)$ & $104(57.7)$ \\
\hline$>5 \mathrm{~km}$ & $7(63.6)$ & $0(0.00)$ & $1(9.1)$ & $3(27.3)$ & $11(6)$ \\
\hline \multicolumn{6}{|l|}{ Watering frequency } \\
\hline Wet season & $\mathrm{N}=45$ & $\mathrm{~N}=45$ & $\mathrm{~N}=45$ & $\mathrm{~N}=45$ & $\mathrm{~N}=180$ \\
\hline Once a day & $32(71.1)$ & $33(73.3)$ & $39(86.6)$ & $31(51.1)$ & $136(70.6)$ \\
\hline Twice a day & $13(28.8)$ & $12(26.7)$ & $6(13.3)$ & $14(48.9)$ & $45(29.4)$ \\
\hline Dry season & $\mathrm{N}=45$ & $\mathrm{~N}=45$ & $\mathrm{~N}=45$ & $\mathrm{~N}=45$ & $\mathrm{~N}=180$ \\
\hline Once a day & $36(80)$ & $27(60)$ & $24(53.3)$ & $28(62.2)$ & $115(63.9)$ \\
\hline Twice a day & $9(20)$ & $18(40)$ & $21(46.7)$ & $17(37.8)$ & $65(36.1)$ \\
\hline
\end{tabular}

$H H C=$ household count, $N=$ number of observation/respondents 


\subsection{Housing}

The hosing of dairy animals in the current study was prioritized based on the age groups. Among the respondents, $83.33 \%$ of them give special attention for calf's and lactating cows; where as $16.67 \%$ of respondents were used comparable management for all animals. Almost all of the households (76.11\%) kept their cattle within family house; while $19.45 \%$ used a separate shelter for their animals and the rest (4.44\%) used open barn/shed or fences within their own compounds (Table 10). Similar housing conditions were also reported by Asrat et al. (2012) in Boditti and Bereda et al. (2012) in Gurage areas. Cattle housed with the family for the fear of thieves, to protect animals from extreme environmental hazards and for ease of husbandry practices such as feeding, watering, milking and waste management. All the interviewed dairy producers in the study area clean the barn every day.

Table10. Housing of cattle in the studied districts of Gurage Zone

\begin{tabular}{|c|c|c|c|c|c|}
\hline \multirow{2}{*}{ Variables } & Enemor & Geta & Mareko & Wolkite & Overall \\
\cline { 2 - 5 } & HHC (\%) & HHC $(\%)$ & HHC $(\%)$ & HHC $(\%)$ & HHC $(\%)$ \\
\hline Housing priority & $\mathrm{N}=45$ & $\mathrm{~N}=45$ & $\mathrm{~N}=45$ & $\mathrm{~N}=45$ & $\mathrm{~N}=180$ \\
\hline Yes & $42(93.33)$ & $39(86.67)$ & $24(53.33)$ & $45(100)$ & $150(83.33)$ \\
\hline No & $3(6.67)$ & $6(13.33)$ & $21(46.67)$ & $0(0.00)$ & $30(16.67)$ \\
\hline Type of housing & $\mathrm{N}=45$ & $\mathrm{~N}=45$ & $\mathrm{~N}=45$ & $\mathrm{~N}=45$ & $\mathrm{~N}=180$ \\
\hline Simple crush & $4(8.89)$ & $2(4.44)$ & $2(4.44)$ & $0(0.00)$ & $8(4.44)$ \\
\hline With people & $38(84.44)$ & $42(93.33)$ & $39(86.67)$ & $18(40.0)$ & $137(76.11)$ \\
\hline $\begin{array}{c}\text { Tethered at yard } \\
\text { and/or kitchen }\end{array}$ & $3(6.67)$ & $1(2.22)$ & $4(15.56)$ & $27(60.0)$ & $40(19.44)$ \\
\hline
\end{tabular}

$H H C=$ household count, $N=$ number of observation/respondents

\subsection{Disease and Health Management}

Health care is one of the management aspects of dairy cattle production. To improve the production of dairy cattle, we should keep their healthy so as to increase our profitability. The most predominant dairy cattle diseases in the study area were FMD, liver fluke, Anthrax, Diarrhea, Blackleg, long warm, Tick, Mastitis, Trypanosomiasis and Dystocia diseases. Diarrhea, FMD and anthrax were the top three prevalent diseases in the study area (Table 11). Their effect is more severe during summer and spring seasons since in those periods, the environment is conducive for different parasites and microbes reproduction.

Table11. Disease Prevalence

\begin{tabular}{|l|l|l|l|l|l|}
\hline & \multicolumn{5}{|c|}{ Rank (No of HHs) } \\
\hline Type of disease & 1 & 2 & 3 & 4 & Index * \\
\hline FMD & 62 & 19 & 3 & 2 & 0.154 \\
\hline liver fluke & 19 & 46 & 1 & 0 & 0.106 \\
\hline Anthrax & 15 & 11 & 72 & 0 & 0.116 \\
\hline Diarrhea & 122 & 11 & 14 & 5 & 0.272 \\
\hline Blackleg & 7 & 6 & 7 & 2 & 0.03 \\
\hline long warm & 5 & 1 & 1 & 7 & 0.016 \\
\hline Tick & 18 & 14 & 23 & 20 & 0.088 \\
\hline Mastitis & 2 & 32 & 47 & 7 & 0.101 \\
\hline Trypanosomiasis & 3 & 0 & 3 & 9 & 0.013 \\
\hline Dystocyia & 41 & 9 & 8 & 5 & 0.104 \\
\hline
\end{tabular}

$H H=$ house characteristics, $N_{\underline{Q}}=$ number of interviewed households

\section{CONCLusions}

The feed resources used for cattle in Gurage area were crop residues; natural grazing and hay were the three top livestock feed resources. Despite this, households make insignificant quantity of concentrate and face critical feed shortage during the dry season. In addition to these major feed resources, Enset by products was also used to feed their cattle. Three types of diseases were identified as major health problems of cattle in Gurage Zone and these involved FMD, Diahorria and Antrax. Livestock health 
problem was not fully addressed in Gurage Zone, because of shortage of veterinary expertise and related facilities. Since disease is one of the major threats of livestock production in the Zone, livestock health management in Gurage Zone as a whole needs urgent attention. Therefore, to improve the situation, use of better feed conservation and utilization techniques, use of improved feeding system and improved animal health services are believed to solve these problems. In order to achieve these, introducing and developing improved forages as sole crops or integrated with cereal crop production (sorghum or maize system), improving sorghum and maize Stover conservation and enhance their utilization by chopping, and treating with urea, improving animal health services including private training and drug supply system with close monitoring and supervision, and strengthening community diseases surveillance and reporting system were very important for the study zone.

\section{ACKNOWLEDGEMENT}

The authors are grateful to the financial assistance received from Wolkite University. The assistance of Guraghe Zone and Woreda office staffs as well as Animal Production and Technology Department staffs are highly appreciated.

\section{REFERENCES}

[1] Alberro, M., 1983. Comparative performance of F1 Friesian $\mathrm{x}$ Zebu heifers in Ethiopia Animal Production. 37: 247 - 252.

[2] Alemayehu M., 2004. Pasture and Forage Resource Profiles of Ethiopia. pp 19. Ethiopia/FAO. Addis Ababa, Ethiopia.

[3] Alemayehu M., 2006. Range Management for East Africa: Concepts and Practices, Sponsored by RPSUD and Printed by A.A.U Printed Press. Addis Ababa, Ethiopia

[4] Asrat A, Zelalem Y and Ajenu N., 2012. Quality of fresh whole milk produced in and around Boditti town, Wolaita, South Ethiopia. African Journal of Animal and Biomedical Sciences, 7(2), pp95.

[5] Belay Duguma, Yisehak Kechero and G.P.J. Janssens, 2011. Analysis of Constraints Facing Urban Dairy Farmers and Gender Responsibility in Animal Management in Jimma Town.

[6] Bereda, A. Yilma, Z., and Nurfeta, A. (2012). Hygienic and microbial quality of raw whole cow's milk produced in Ezha district of the Gurage zone, Southern Ethiopia. Wudpecker J. Agri. Res., 1(11), 459 465.

[7] Beyene T, Tegene N. and Ayana A., 2011. Effect of farming systems on livestock feed resources and feeding systems in Benishangul-Gumuz region, western Ethiopia. Vol. 1(1) pp. 020-028

[8] CACC (Central Agricultural Census Commission). 2002. Ethiopian agricultural sample enumeration report, held 2001/02 (1994 EC). Addis Ababa, Ethiopia.

[9] CSA (Central Statistics Authority), 2008. Central Statistics Authority of the Federal Democratic Republic of Ethiopia. Agricultural sample survey 2007/2008. Vol. II. Report on livestock and livestock characteristics. Statistical bulletin. Addis Ababa, Ethiopia: CSA.

[10] CSA (Central Statistics Authority), 2009. Agricultural sample survey 2008/09. Report on livestock and livestock characteristics. Statistical bulletin 446. Addis Ababa, Ethiopia: CSA.

[11] CSA (Central Statistics Authority), 2010/11. Agricultural sample survey 2010/2011. Vol. II. Report on livestock and livestock characteristics. Statistical Bulletin. Addis Ababa Ethiopia

[12] FAOSTAT, 2009. FAO statistical yearbook. Rome: Food and Agriculture Organization of the United Nations.

[13] Holecheck J L, Pieper R D and Herbel CH 2005 Range management: Principles and practices. 5th Edition. (Pearson: New Jersey). 607p.

[14] IBC (Institute of Biodiversity Conservation), 2004. State of Ethiopia's Animal Genetic Resources Country Report. A Contribution to the First Report on the State of the World's Animal Genetic Resources. Addis Ababa, Ethiopia.

[15] Kiwuwa, G. H., J.C.M. Trail, M. Y. Kurtu, G. Worku, F.M. Anderson and J. Durkin, 1983. Crossbred dairy cattle productivity in Arsi Region, Ethiopia. International Livestock centre for Africa (ILCA). Research report No. 11, 1-29. 
[16] MoARD, 2004. Market-oriented development master plan. Addis Ababa, Ethiopia.

[17] SPSS (Statistical Package for Social Science), 2007. Statistical Package for Social Science Inc. Chicago, Illinois, USA). Version 20.

[18] Yoseph M., Azage T., Alemu Y. and N.N. Ummuna, 2003. Milk Production, milk composition and body weight change of crossbred dairy cows in urban and peri-urban dairy production systems in Ethiopia. pp. 185-192. Proceedings of the 12th annual conference of the Ethiopian Society of Animal Production (ESAP) held in Addis Ababa, Ethiopia, August 22-24, 2002.

Citation: Tesfaye Feyisa Aduna, Wondossen Ayalew, “Assessment of Dairy Cattle Management in Gurage Zone, Southern Nation Nationalities and Peoples Region, Ethiopia” International Journal of Research Studies in Agricultural Sciences (IJRSAS), 2019; 5(4), pp. 1-10, http://dx.doi.org/10.20431/2454-6224.0504001

Copyright: (C) 2019 Authors. This is an open-access article distributed under the terms of the Creative Commons Attribution License, which permits unrestricted use, distribution, and reproduction in any medium, provided the original author and source are credited. 